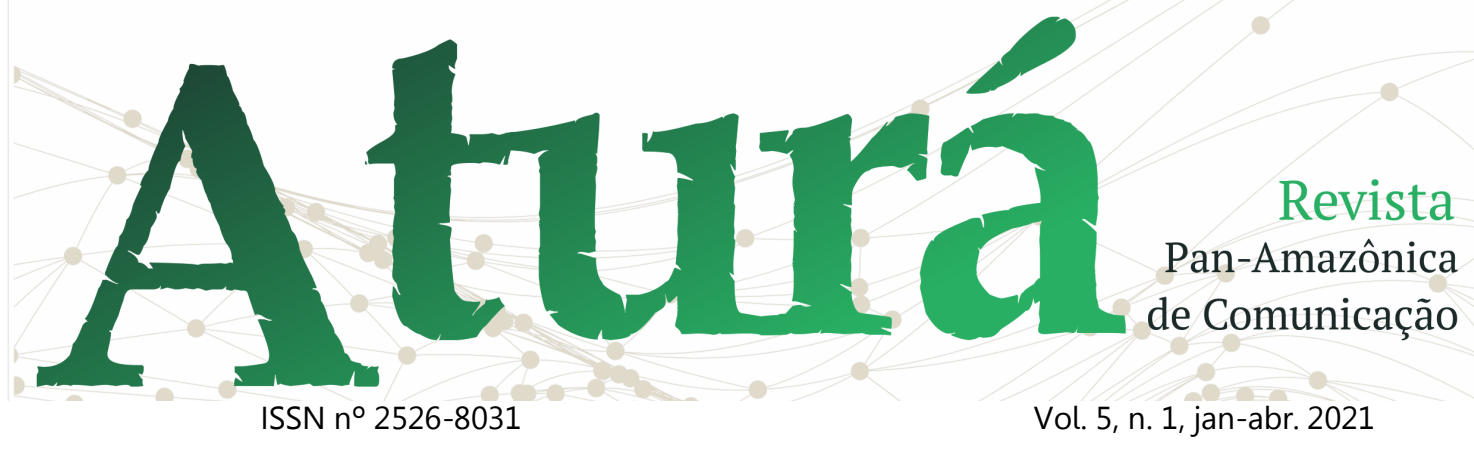

\title{
UMA CULTURA "PARÁ TE ENCANTAR": A REPRESENTAÇÃO DA IDENTIDADE PARAENSE NO VÍDEO-PROPAGANDA DO GOVERNO DO ESTADO
}

A "Pará te encantar"1 culture: the representation of the Pará's identity in the state government's propaganda video

Una cultura "Pará te encantar": la representación de la identidad del paraense en el video de propaganda del gobierno estatal

Kleyse Costa Vaz Santana Prado, Universidade Federal do Pará ${ }^{2}$ Luiz LZ Cezar Silva dos Santos, Universidade Federal do Pará ${ }^{3}$

\section{RESUMO}

Em 2017, a Secretaria de Comunicação e a Secretaria de Turismo do Estado do Pará lançaram uma campanha publicitária denominada "Pará te encantar". Ao assistir ao vídeopropaganda, percebe-se a intenção principal de atrair turistas externos, porém, ao mesmo tempo, o vídeo-propaganda acaba também suscitando a curiosidade dos paraenses em conhecer melhor a diversidade do seu próprio estado. No comercial ocorre a reprodução de imagens que representariam aquilo que seria a cultura do Pará e o que seria "ser paraense". Este artigo representa as primeiras impressões de uma pesquisa de mestrado em andamento, com o apoio da CAPES. A intenção é promover a reflexão a respeito da construção da representação da identidade cultural do paraense no comercial publicitário, e sobre a existência de elementos que sirvam também como fomento para estereótipos culturais. Serão analisados os elementos linguísticos e iconográficos, buscando conhecer as possibilidades de interpretação e a construção de sentidos e discursos presentes no vídeo-propaganda analisado.

\footnotetext{
1 "Pará encantar" means "To enchant you", but "Pará" is also the name of a Brazilian state in the north of the country, where part of the Amazon Forest is located. The title would be similar to "A culture to enchant you". ${ }^{2}$ Mestranda no Programa de Pós-Graduação em Comunicação, Cultura e Amazônia - PPGCOM/UFPA. Membro do Gruppu - Grupo de Pesquisa em Propaganda e Publicidade. Bolsista CAPES. E-mail: kleyse.prado@gmail.com.

${ }^{3}$ Doutor em História pela PUC/SP. Professor da Faculdade de Comunicação - FACOM/ILC/UFPA e do Programa de Pós-Graduação em Comunicação, Cultura e Amazônia - PPGCOM/UFPA. Coordenador do Gruppu - Grupo de Pesquisa em Propaganda e Publicidade. E-mail: lzcezar@ufpa.br.
} 


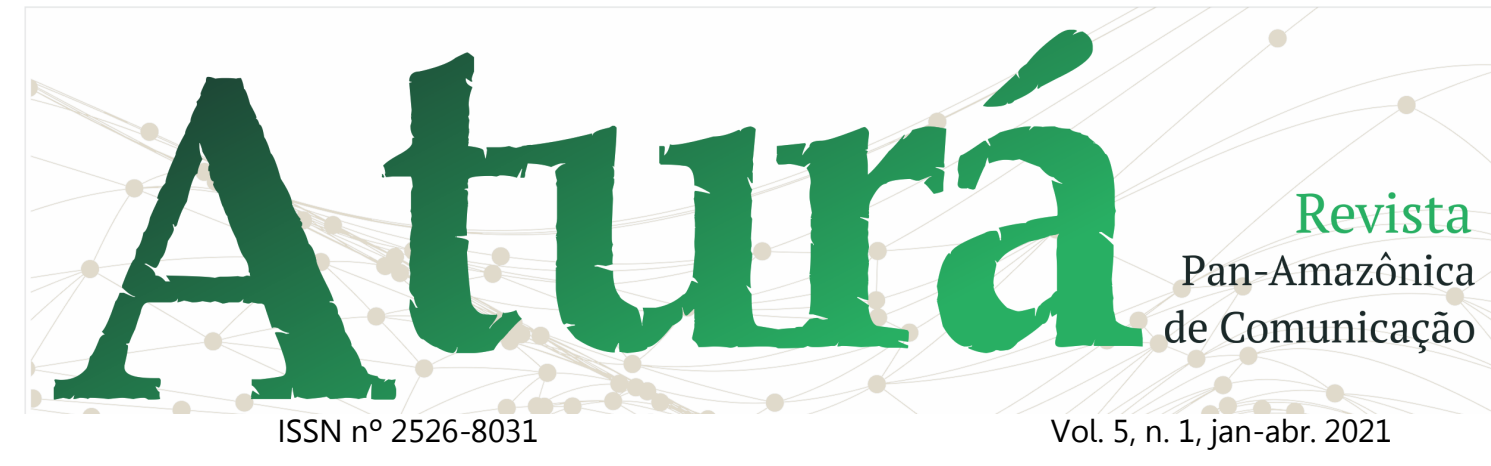

PALAVRAS-CHAVE: vídeo-propaganda; identidade cultural; Estado do Pará; turismo cultural.

\begin{abstract}
In 2017, the Secretariat of Communication and the Secretariat of Tourism of the State of Pará, Brazil, launched an advertising campaign called "Pará te encantar". When we watch the advertising video, we realize the main intention of attracting foreigners, but at the same time, the advertising video also encourages the people of Pará to discover more about the diversity of their own state. The commercial reproduces images that represent what would be the culture of Pará and what would be "being from Pará", native. This study represents the first impressions, part of an ongoing research, developed with the support of CAPES, a Brazilian institution that promotes research. The intention is to promote reflection on the construction of the representation of the cultural identity of the people of Pará in the video, and on the existence of elements that also serve to foster cultural stereotypes. Linguistic and iconographic elements will be analyzed, seeking to understand possibilities of interpretation and construction of meanings and discourses present in video advertising.
\end{abstract}

KEYWORDS: advertising video; cultural identity; State of Pará; cultural tourism.

\title{
RESUMEN
}

En 2017, la Secretaría de Comunicación y la Secretaría de Turismo del Estado de Pará, Brasil, lanzaron una campaña publicitaria denominada "Pará encantar". Cuando vemos publicidad en video, vemos la principal intención de atraer turistas extranjeros, pero al mismo tiempo, la publicidad en video también despierta la curiosidad de la gente de Pará por conocer más sobre la diversidad de su propio estado. En el comercial se reproducen imágenes que representarían lo que sería la cultura de Pará y lo que sería "ser de Pará", un nativo. Este estudio representa las primeras impresiones, parte de una investigación en curso, desarrollada con el apoyo de CAPES, una institución brasileña que promueve la investigación. La intención es promover la reflexión sobre la construcción de la representación de la identidad cultural de Para en los anuncios publicitarios, y sobre la existencia de elementos que también sirven de estímulo a los estereotipos culturales. Se analizarán los elementos lingüísticos e iconográficos, buscando conocer las posibilidades de interpretación y construcción de significados y discursos presentes en el video publicitario analizado.

PALABRAS CLAVE: vídeo publicitario; identidad cultural; Estado de Pará; turismo cultural. 


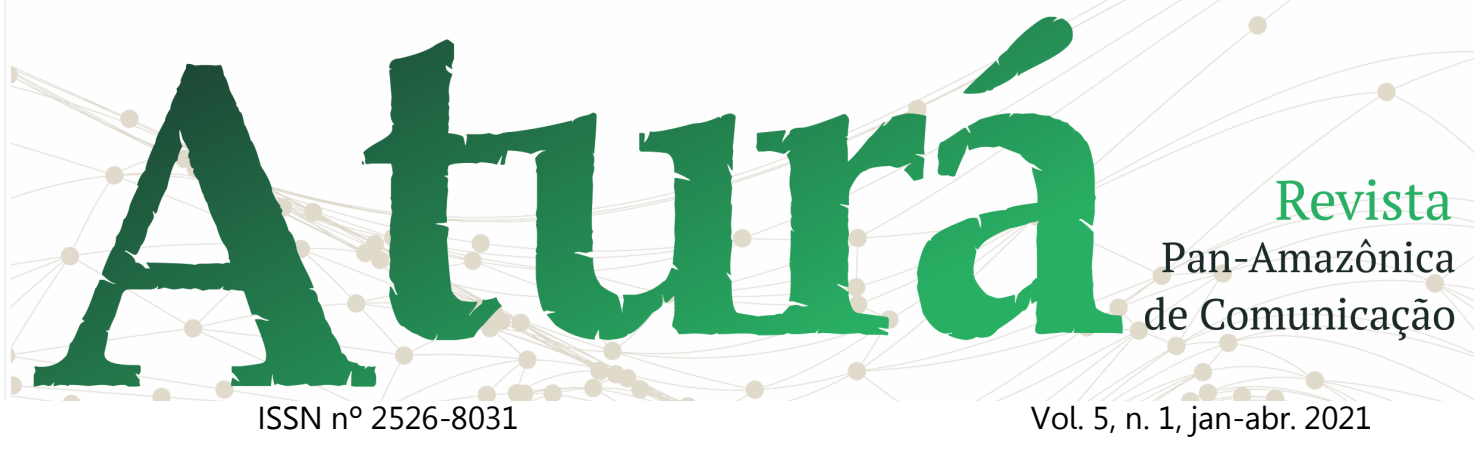

\section{Introdução}

A curiosidade, o desafio das descobertas, movem os seres humanos, os transforma e transforma o ambiente a sua volta. Fidalgo (1996) afirma que a curiosidade se caracteriza pela instabilidade, pela incapacidade de permanecer no mesmo sítio, no mesmo conhecimento. Segundo ele, "temos prazer na atividade dos sentidos, independentemente da sua utilidade. Gostamos de ver, de ouvir, cheirar, degustar, tocar, tão só pelo fato de o fazermos" (FIDALGO, 1996, n.p). E assim, milhares de pessoas todos os anos, movidas por esta curiosidade, tornam-se turistas e buscam novas experiências a fim de saciar essa necessidade que Fidalgo evoca.

Antes de mais, a curiosidade não se fica por aquilo que lhe está próximo; pelo contrário, procura o que está longe. Mas ao chegar ao longe, torna-o perto, e, assim, vai matando a distância que sempre procura. Tem de passar necessariamente a outro, tem de buscar incessantemente novas distâncias. Há, pois, um desassossego contínuo, uma excitação permanente. Sempre e sempre em busca da novidade, da mudança das coisas, não para compreender, que para isso é preciso permanecer, mas tão só para ver, para satisfazer o desejo e a gulodice da vista. O que se ganha é a distração. (FIDALGO, 1996, n.p).
Mantendo esse pensamento, podemos refletir a respeito das propagandas oficiais turísticas, que são previamente construídas com a intenção de estimular essa curiosidade, utilizando vários recursos e diversos tipos de linguagens para alcançar esse objetivo. Considerando que a linguagem age como mediadora entre o homem e a cultura (SCHAFF, 1977), as propagandas, tão repletas de linguagens, acabam participando dessa mediação. No caso da propaganda turística, por exemplo, o turista acaba sendo induzido a interpretar, criar expectativas sobre uma percepção de como será o seu destino baseado no que viu, ouviu ou leu nas propagandas.

\section{Com o exemplo dado} anteriormente, pensar a respeito dessa mediação que a propaganda turística faz entre os turistas e outro lugar, outra cultura, diferentes, levanta uma série de questionamentos sobre como a propaganda se relaciona com a identidade cultural. Ela apenas reflete ou também influencia na sua construção? 


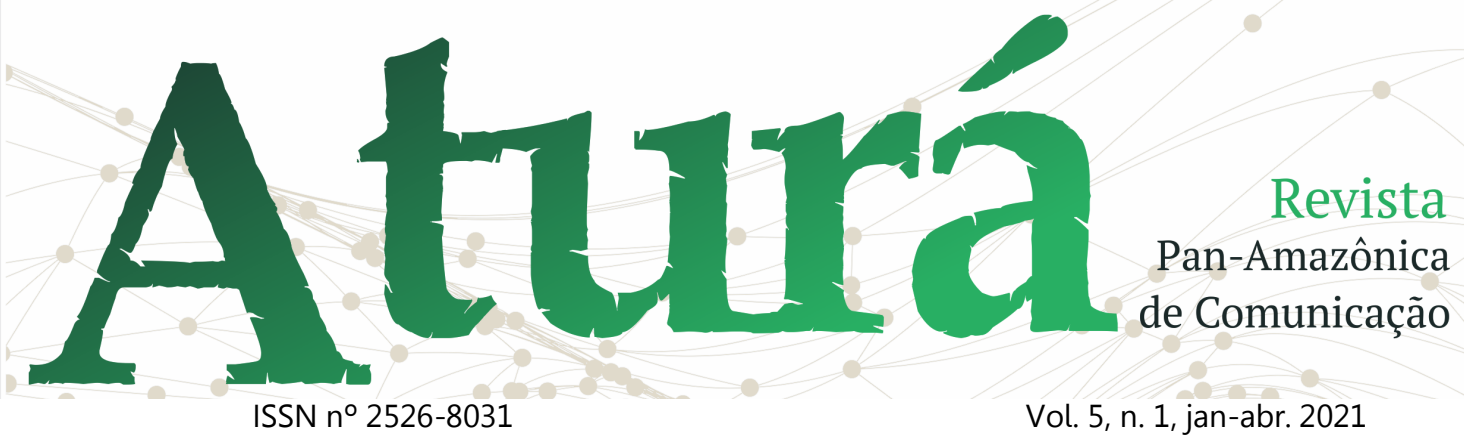

Será que as propagandas turísticas, principalmente as que focam no produto turismo cultural, de fato refletem a cultura e a realidade daquele lugar? $O$ que é estereótipo na propaganda, qual o seu papel, como interfere na construção social?

Diante disso, propomos uma pesquisa que aborde estes questionamentos aplicados ao caso de uma propaganda turística governamental específica. Em 2017, a Secretaria de Comunicação e a Secretaria de Turismo do Estado do Pará lançaram uma campanha denominada "Pará te encantar", buscando, principalmente, atrair turistas de fora do estado. A peça principal da comunicação publicitária do Governo foi um comercial no formato de clipe musical, que chamaremos daqui em diante de vídeo-propaganda, expondo várias imagens que representavam aquilo que seria o estado do Pará e o povo paraense, sua cultura, seus costumes. O referido vídeo-propaganda foi um dos 5 comerciais finalista, de todo o Brasil, em

2018, do concurso de Melhor Comercial Regional, promovido pela emissora SBT.

Com essas considerações é que buscamos desenvolver um estudo que reflita sobre como o estado do Pará foi retratado pelo seu próprio governo em uma vídeo-propaganda que circulou nacionalmente, via internet; quais estereótipos podem estar sendo reforçados; como os turistas de fora do estado poderiam interpretar essas mensagens e se o paraense se reconhece nesse vídeo-propaganda como participante desta identidade cultural que se buscou representar.

\section{Identidades e culturas}

Identidade é um termo onde cabe, cada vez mais, uma série de questionamentos. Isso porque, como afirma Stuart Hall (2006) em seus estudos sobre a cultura na pós-modernidade, este conceito tem mudado tanto quanto as mudanças rápidas e contínuas que ocorrem na contemporaneidade. O homem pós-moderno seria, então, sem uma identidade fixada, essencial ou 


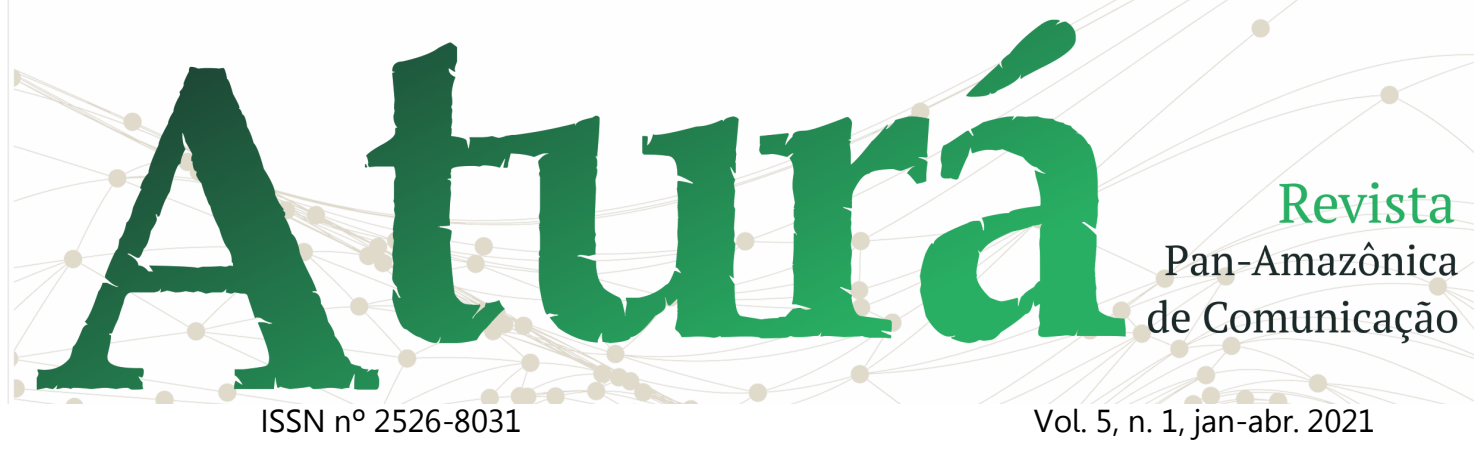

permanente, "formada e transformada continuamente em relação às formas pelas quais somos representados ou interpelados nos sistemas culturais que nos rodeiam" (HALL, 2006, p. 13). Esta característica de assumir "diferentes identidades em momentos distintos" estaria relacionada ao processo de globalização como sendo sua consequência. A globalização é um movimento de expansão, que redimensiona o espaço, tempo e a densidade de relações e fluxos materiais e imateriais. Traz consigo uma nova concepção de "sociedade", não mais como um sistema bem delimitado, e sim compreendida a partir do modo "como a vida social está ordenada ao longo do tempo e do espaço" (GIDDENS, 1991, p. 64).

Dito isto e tendo em mente que a organização do espaço interfere diretamente nas relações sociais, e que o tempo representa valor (tanto para sociedades tradicionais como para a pósmodernidade) é possível traçar as primeiras linhas que relacionam a globalização com as mudanças na identidade cultural. A globalização contribui para ampliar o alcance das misturas, pois promove a descentralização (LACLAU, 1990) dos elementos culturais que, assim, são apropriados por distintos povos $\mathrm{e}$ adaptados a diferentes culturas, modificando sua identidade. Aquilo que é diferente está mais acessível e o diferente também é parte importante na construção da identidade. Silva (2000) diz que ao contemplar aquilo que não somos, podemos conseguir definir parte do que somos. "Assim como a identidade depende da diferença, a diferença depende da identidade. Identidade e diferença são, pois, inseparáveis" (SILVA, 2000, p. 75).

Sendo assim tão estimulada, a experimentação cultural torna-se um produto que se assemelha a outros bens de consumo produzidos para serem consumidos pelas massas, resultado da indústria cultural

(ADORNO; HORKHEIMER, 1985). Ono (2004) diz que a cultura do consumo é uma das 


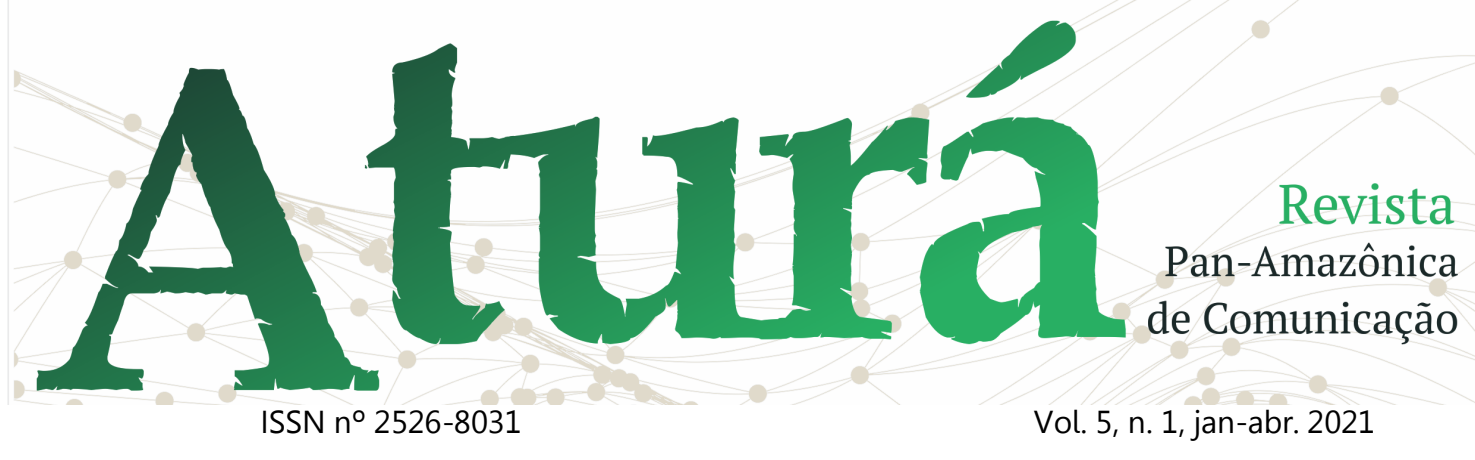

principais referências que validam comportamentos e valores nas sociedades globalizadas, sendo um de seus eixos. O turismo cultural cresce amplamente todos os anos, pois a experiência turística proporciona diversas vivências: sensoriais, sociais, culturais, econômicas. O turismo cultural pode ser considerado, como afirmam Zeppel e Hall (1991), como um turismo experiencial. O que se oferece é um produto com sensações e experiências emocionais, onde a cultura é convertida em um produto que o consumidor compra, não apenas bens e serviços, mas a vivência de experiências e sensações (SCHMITT, 2002).

A busca pelo produto cultural encontra explicação na necessidade de os indivíduos confrontarem suas origens com a realidade socioeconômica da atualidade. Isso faz com que o turismo cultural represente muito mais do que ver e conhecer estilos de vida, folclore ou arte de outras culturas, mas propicie experimentar uma realidade diferente, encontrando a interação entre o passado e o presente e sinalizando, para alguns, parâmetros do futuro. (Índice de Competitividade do Turismo Nacional, 2015, p. 78)

Podemos aplicar essas reflexões ao nosso contexto. Em 2015, de acordo com o relatório do Índice de Competitividade do Turismo Nacional, publicado pelo Ministério do Turismo, Belém ocupava a $6^{\mathrm{a}}$ posição no ranking de municípios com produção cultural associada ao turismo obtendo 86,6 pontos na escala. Infelizmente não houve publicação mais recente deste índice, porém existe a probabilidade de que a quantidade de pontos tenha aumentado fazendo com que a cidade tenha, possivelmente, subido no ranking, visto que, ainda de acordo com este relatório, a pontuação da capital paraense vem subindo desde 2010, aumentando 13,4 pontos até a data desta última pesquisa. No Estudo da Demanda Turística Internacional publicado pelo Ministério do Turismo em 2017, mostra que a motivação dos turistas estrangeiros ao visitar Belém por interesses pela cultura aumentou de 5,2\% dos visitantes em 2012 para 32,6\% em 2016. Isto mostra como a cultura da região desperta a curiosidade e atrai os turistas.

Com o objetivo de estimular ainda mais o turismo para o estado do Pará, em 


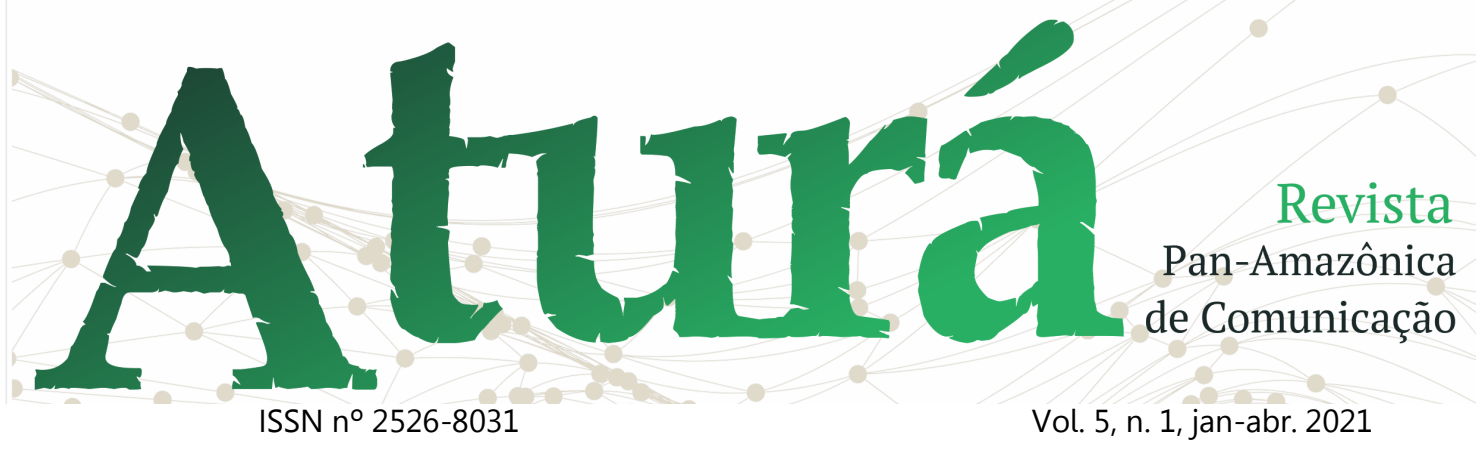

2017 a Secretaria de Comunicação e a Secretaria de Turismo do Estado do Pará lançaram a campanha "Pará te encantar". O que se percebe no vídeo-propaganda são, basicamente, dois elementos principais: de um lado aqueles que vão além do turismo de sol e praia ressaltando as festas, a religiosidade, os monumentos, a gastronomia; de outro lado, as paisagens, a natureza exuberante paraense, elementos que poderiam atrair os turistas para uma experiência mística e ecológica. Diante disso, nos chama a atenção a seguinte declaração presente no Índice de Competitividade do Turismo Nacional (2015, p. 78): "a cultura de um destino se expressa por meio de identidade, valores, atitudes e condutas e, em alguns casos, pelo imaginário presente nos comportamentos das comunidades". O imaginário, segundo Orlandi (2020), é o que nos liga a nossas condições materiais de existência, uma vez que a relação entre linguagempensamento-mundo não é tão evidente, obrigando o sujeito a interpretar, a construir sentido. O imaginário é toda essa bagagem que o indivíduo carrega e é única, exclusiva de cada um, faz parte da maneira como o sujeito é constituído na produção de sentidos (ORLANDI, 2020) e, como na afirmação citada acima, é um meio pelo qual a cultura também se expressa.

Bueno (2002) mostra como foi construído um imaginário de uma Amazônia homogênea e estereotipada. $O$ "Novo Mundo", as imagens de florestas e largos rios, intocados, inabitados são o que primeiro vem a mente das pessoas. Todo esse "mistério" desperta a curiosidade em conhecer essa região "primitiva", a cultura mística e peculiar de um povo que ainda vive "isolado" e o Pará, como portal de entrada da Amazônia, torna-se um caminho para aqueles que buscam essa experiência "exótica". Ao acessar, por exemplo, o site Visit Pará (http://www.paraturismo.pa. gov.br/, oficial do governo estadual para incentivar o turismo), as imagens que mais se destacam, sendo as primeiras e maiores, são de festas típicas (folclóricas e religiosas) e as fotografias da natureza. 


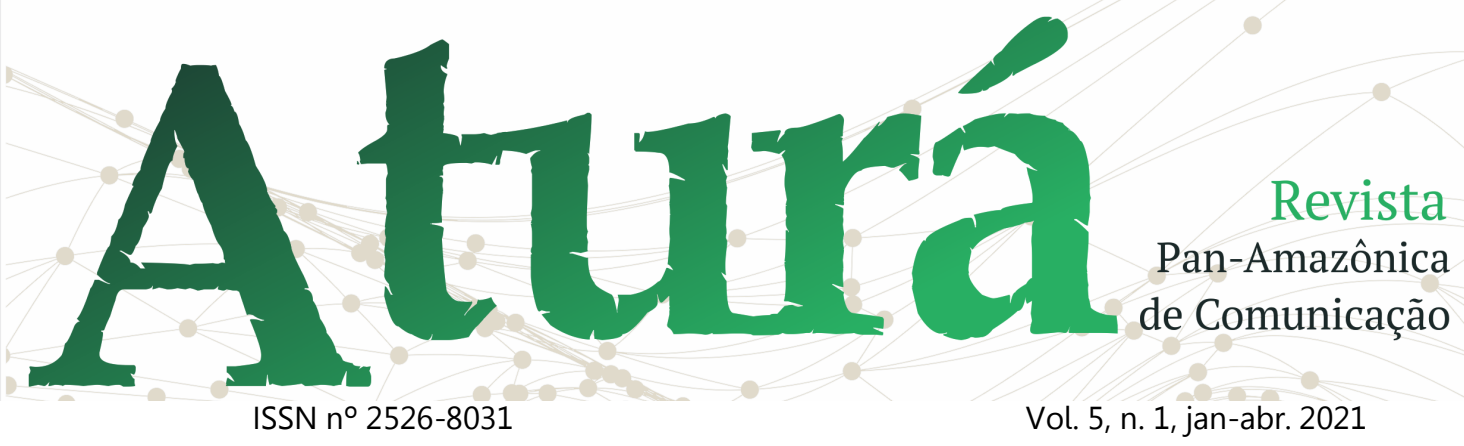

As repetições constantes destes aspectos nas propagandas turísticas podem refletir uma Amazônia com símbolo padronizado e estereotipado para os turistas, uma "representação simbólica da região, institucionalizada por parâmetros socioeconômicos e culturais publicizados em escala mundial pelo campo da comunicação" (AMARAL FILHO; CASTRO; COSTA, 2015, p. 107).

Hall (2006) fala dessa homogeneização como consequência do processo de criação de uma cultura nacional. As diferenças regionais, étnicas, entre outras, são subordinadas de forma a criar padrões, a criar um discurso que constrói sentidos capazes de influenciar e organizar nossas ações. "Não importa quão diferentes seus membros possam ser em termos de classe, gênero ou raça, uma cultura nacional busca unificá-los numa identidade cultural, para representá-los todos como pertencendo à mesma grande família nacional" (HALL, 2006 , p. 59). As culturas nacionais, que são aquelas que dão ao indivíduo a sensação de pertencimento a um grupo, do sentimento unificado e coletivo de nação, são compostas também de símbolos e representações, sendo assim um discurso. Esse discurso é repleto de memórias que conectam o presente ao passado ou à imagem que se tem dele (HALL, 2006).

É neste sentido que cabe refletir, se essas apresentações sonoras e imagéticas que, por tantas vezes são tão repetitivas e padronizadas, são capazes de representar a identidade do Pará e do paraense. Neto e Barbosa (2007) afirmam que a publicidade está relacionada à identidade de um sujeito na medida em que faz representações com a intenção de gerar uma identificação e até mesmo uma projeção do público para a realidade apresentada no vídeo-propaganda, por exemplo. Traz no seu discurso valores contemporâneos capazes de substituir os que antes ancoravam a identidade (etnia, gênero, classe etc.), fazendo, assim, construções com as representações do cotidiano que não são necessariamente reais. Desta maneira, a publicidade pode ajudar a moldar a identidade do sujeito, 


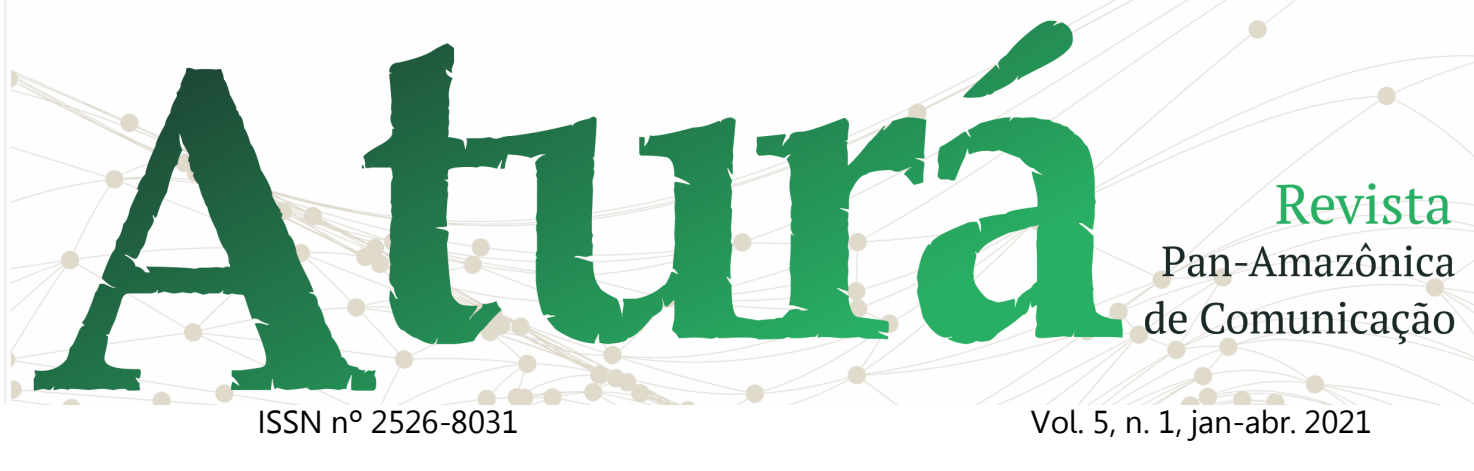

pois intervém em questões da sua sociabilidade. Pode, também, reforçar essas visões estereotipadas dos destinos de viagem e os nativos, uma vez que as propagandas voltadas ao incentivo do turismo utilizam estereótipos com o objetivo de formar motivações e desejos, pois são uma maneira de ressaltar o que determinado destino tem de mais relevante (ORNELAS; PEREIRA, 2005, p. 11).

\section{Metodologia}

Para compreender melhor a mensagem e o discurso presentes no vídeo-propaganda do governo do Pará, como foram construídos e como este discurso se relaciona com a identidade cultural do paraense, será realizada, primeiramente, uma decupagem, recortando e descrevendo cena a cena, quadro a quadro, para melhor perceber todos os elementos visuais, sonoros e textuais que compõe o vídeopropaganda. Em seguida, será desenvolvida a análise dos elementos plásticos (cores, texturas, formas), das

imagens representadas (lugares, objetos, paisagens), das técnicas aplicadas (enquadramento, movimentos de câmera, edição) e do áudio (música, efeitos sonoros).

Para construir a reflexão a respeito dos sentidos construídos e representados pelo vídeo-propaganda, será utilizada na pesquisa a metodologia de Análise do Discurso (AD). Este método propõe a procura pelo real do sentido em sua materialidade linguística e histórica (ORLANDI, 2009). Analisar um discurso é ir além do seu conteúdo, da mensagem, da interpretação, e buscar entender como o objeto produz sentido. $\mathrm{Na} A D, \mathrm{a}$ comunicação é tida como um processo onde emissor e receptor estão ao mesmo tempo em processo de significação. Conforme Orlandi (2009), analisar o discurso é analisar o homem falando e compreender a língua fazendo sentido enquanto trabalho simbólico.

$\mathrm{Na}$ busca pelas respostas aos questionamentos realizados anteriormente, faz-se necessário realizar uma análise do discurso do vídeo- 


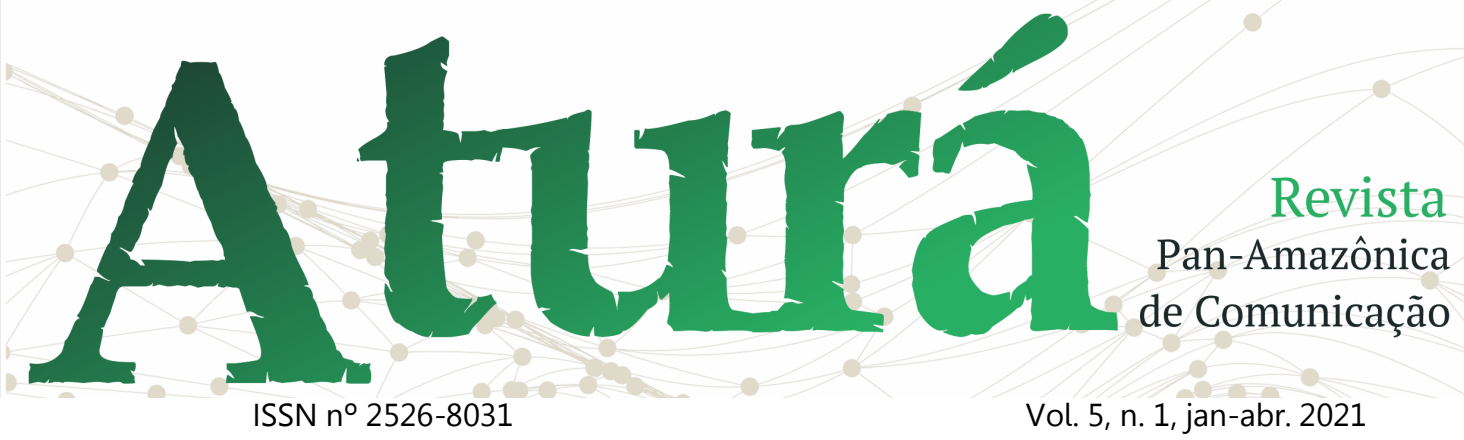

propaganda, pois é o discurso que possibilita que tanto o homem como a realidade que ele vive sejam transformados, deslocados, permaneçam ou tenham continuidade, conforme afirma Orlandi (2009). O lugar a partir do qual o sujeito fala também constitui o que ele diz. Ao construir significados e significar-se simultaneamente, o homem é sujeito da língua e da história e, ao mesmo tempo, está sujeito a elas, pois elas o atravessam e o afetam (ORLANDI, 2009). Assim, podemos afirmar, que discurso e identidade estão diretamente ligados. Esta análise permitirá perceber quais são e como são construídos os discursos que moldam a identidade cultural e como se relacionam com os estereótipos.

\section{O vídeo-propaganda}

Com o desenvolvimento da pesquisa, poderemos observar melhor como são construídas as representações acerca da identidade cultural do Pará e desenvolver uma análise comunicacional, sociológica, antropológica e cultural sobre ela. Inicialmente, algumas reflexões já podem ser feitas, como, por exemplo, ao observar o título do comercial "Pará te encantar". A palavra "encantar", de acordo com o dicionário Aurélio, pode significar maravilhar-se, envolver ou ser envolvido por algo sedutor; bem como enfeitiçar, submeter algo ou alguém à magia ou encantamento. Esse termo pode reforçar o estereótipo existente de que a região Norte do Brasil, e consequentemente a Amazônia, é mística, misteriosa, encantada.

Ao observar o vídeo-propaganda do governo do Pará, ao mesmo tempo em que a letra da música diz "encantar", aparecem imagens de pessoas: na primeira vez indígenas, na segunda uma senhora deitada em uma rede, na terceira uma mulher negra, e na quarta vez uma senhora sorrindo segurando um guardachuva. Isto pode se referir ao "encanto" do Pará não estar apenas nas paisagens, mas no paraense como povo "encantador".

Outro aspecto que também podemos interpretar no trecho da música 


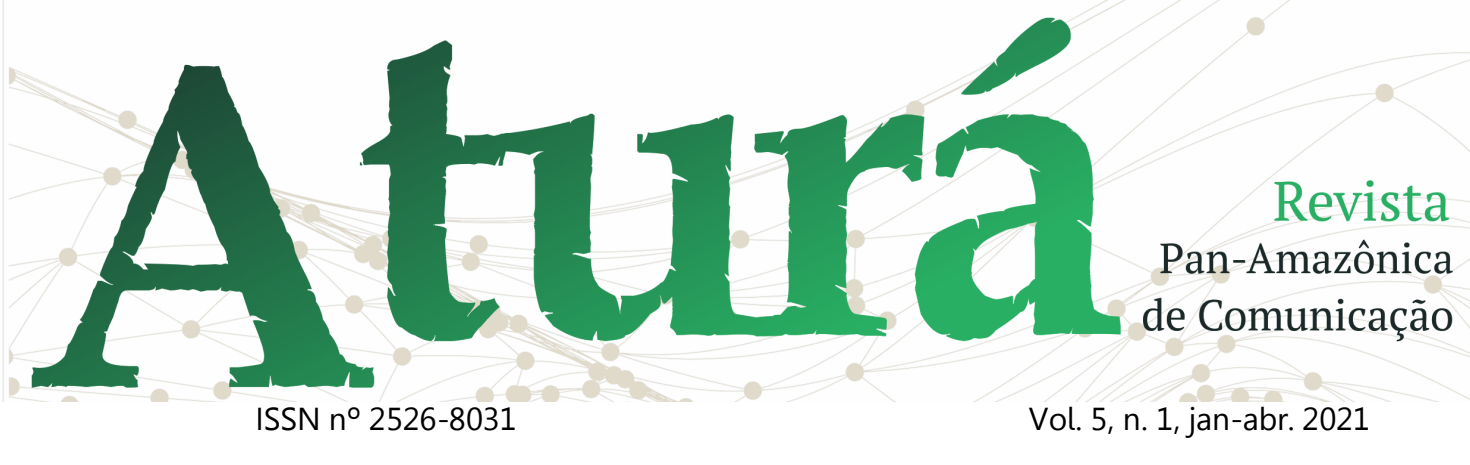

"Deixa o Pará te encantar, que o Pará se encanta também" é que o Pará já possui um encanto próprio, capaz de encantar o turista, porém a presença do turista dá um encanto a mais ao Pará. Há uma troca representada inclusive na letra da música quando afirma que "o Pará te encantar e você encanta o Pará". Esse sentido de troca, de simbiose, de sustentabilidade, é muito forte em todo o vídeo-propaganda. Nele são mostradas diversas imagens de localidades paraenses próximas às florestas, pessoas desfrutando dos recursos naturais, nadando nos rios, caminhando pela mata. Isso transmite uma ideia sobre como é viver no Pará, como se cidade e floresta, pessoas e natureza convivessem em equilíbrio numa relação mutualmente vantajosa onde tanto os seres humanos como a natureza se beneficiam, uma simbiose, trazendo à memória a ideia que se tem de como os índios viviam e vivem na floresta. É uma associação subjetiva à ideia de desenvolvimento sustentável.

Um exemplo interessante para essa ideia de sustentabilidade pode ser visto em uma montagem de imagens no comercial que associam diretamente a cidade com a floresta. Nessas imagens (Figuras 1 e 2) são mostradas canoas descendo pelo rio no meio da mata e, logo em seguida, são mostrados carros trafegando na avenida arborizada em meio a cidade. As imagens são similares, inclusive nos enquadramentos e posição dos elementos na composição.

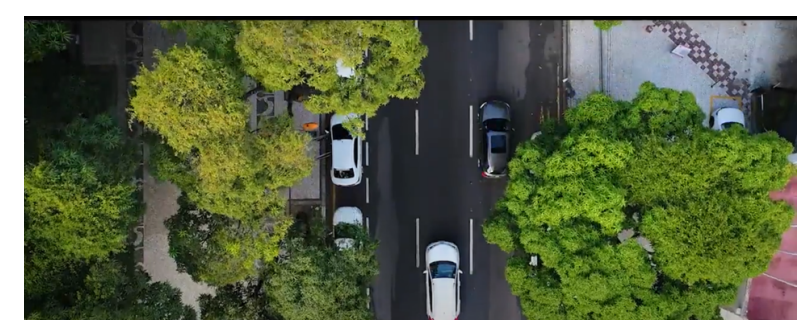

Figura 1- Imagem de avenida

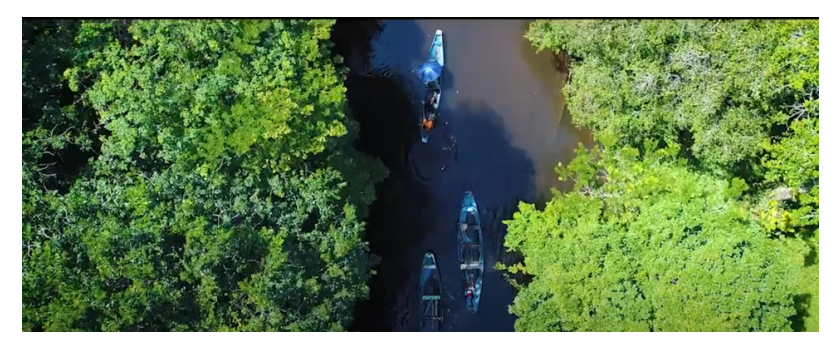

Figura 2- Imagem de canoas no rio em meio a floresta

Outras imagens também carregam essa ideia. Elas mostram a cidade emergindo em meio a floresta e essa composição aparece várias vezes no vídeo-propaganda sendo, inclusive, a 


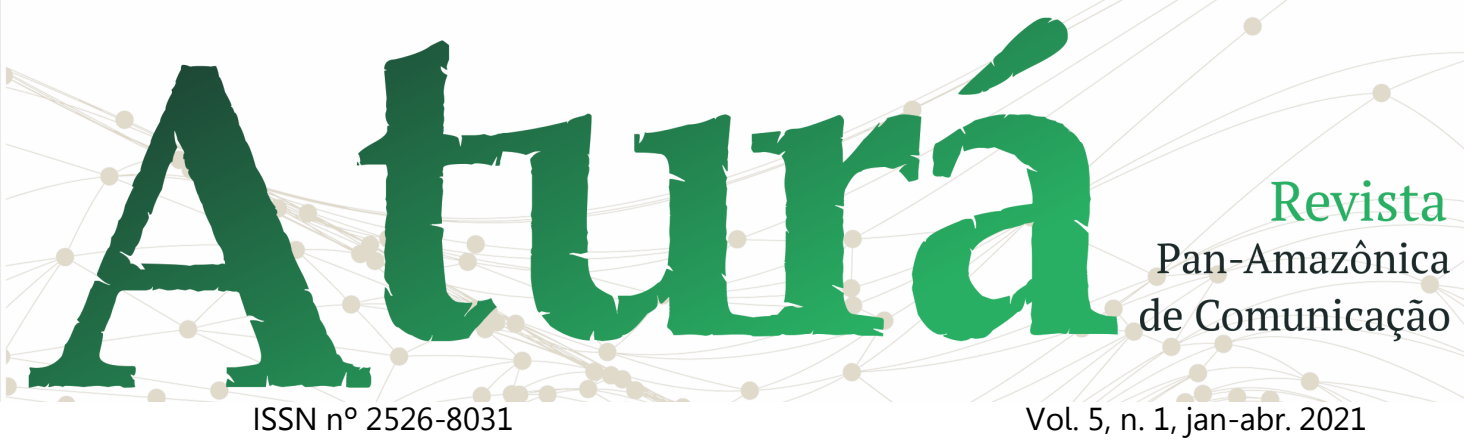

primeira imagem (Figura 3). Podem, ainda, ter a intenção de demonstrar que na Amazônia também tem cidades, mostrando ao turista que ele pode desfrutar dos espaços urbanizados, se assim desejar. Porém, pouco é mostrado da rotina da cidade. Não são expostos muitos pontos turísticos urbanos, dando destaque à floresta como diferencial na experiência de turismo no Pará.

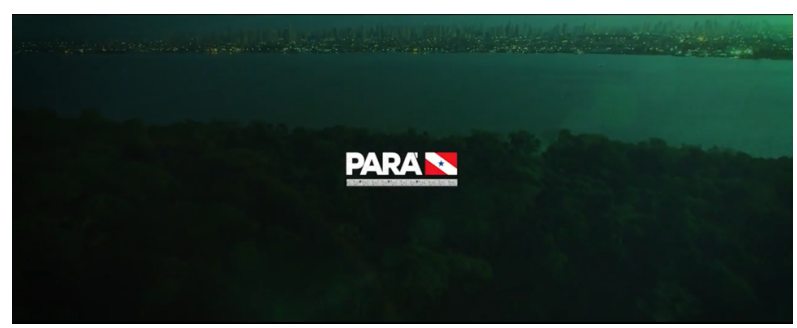

Figura 3- Imagem de abertura do vídeopropaganda mostra floresta em primeiro plano e cidade ao fundo

Outra imagem interessante, apesar de passar rapidamente no vídeopropaganda, é a de um artista pintando a fachada de um prédio com o estilo grafite. Essa imagem aparece quando a música convida o turista a ver as muitas culturas que têm no Pará. Apesar da belíssima obra imagética apresentada no vídeo-propaganda, na realidade a cidade

de Belém, em particular, sofre com vandalismo através de pichações em diversos lugares, incluindo o centro da cidade e prédios históricos, bem como de pontos turísticos. Em 27 de julho de 2020, por exemplo, o jornal O Liberal ${ }^{4}$ noticiou a pichação que ocorreu em menos de 24 horas depois do edifício-sede dos Correios, um dos prédios históricos mais importantes da cidade construído em 1942, ter sido revitalizado.

Os indígenas aparecem em dois momentos no vídeo-propaganda e em ambos estão sendo retratados realizando rituais na floresta, com pinturas típicas, lembrando aquela visão europeia, o estereótipo do índio selvagem que, ainda, desperta a curiosidade de muitos turistas nacionais e estrangeiros. As mulheres jovens são mostradas de forma sedutora. Uma delas está deitada em um trapiche, com os cabelos espalhados pelo chão, pernas à mostra e a luz amarela do sol que dá à cena o mesmo tom da sua pele

\footnotetext{
4 Disponível em: https://www.oliberal.com/belem/nova-pintura-dafachada-da-sede-historica-dos-correios-evandalizada-1.289277. Acesso em ago. 2020.
} 


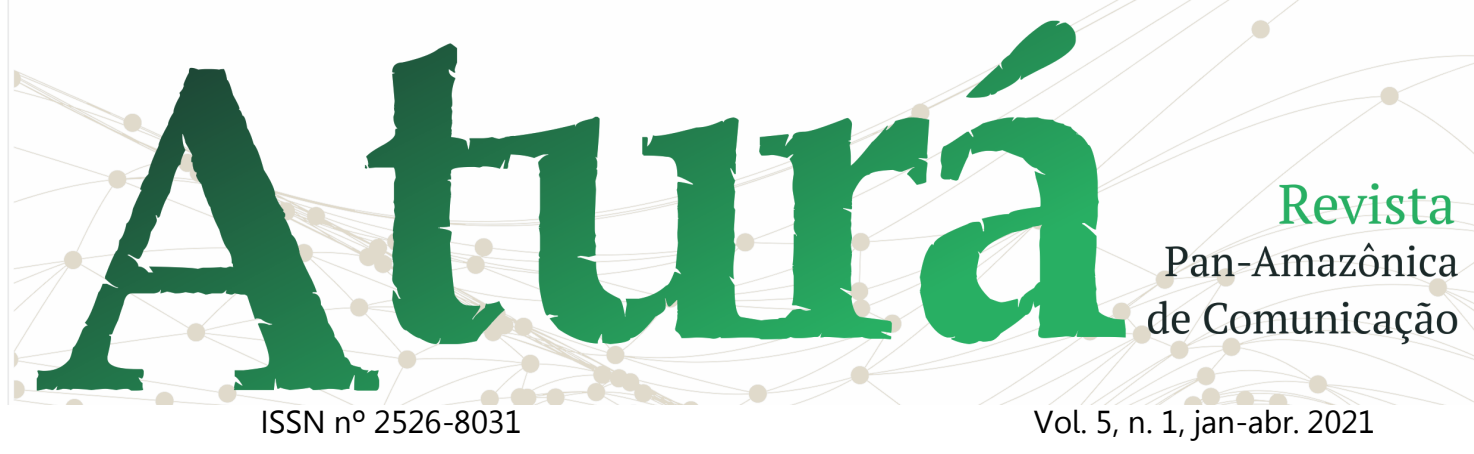

"dourada". Em outra cena, no mesmo momento em que a música diz "Deixa o Pará te encantar" aparece uma mulher negra, jovem, com olhar sedutor, balançando os cabelos longos, soltos e volumosos. Toda a cena também tem os tons de sua pele.

Além das mulheres jovens, aparecem, também, homens e mulheres idosos. Estes sempre retratados muito simpáticos e receptivos. Os homens jovens estão nadando ou em canoas. Existe a representação de uma certa diversidade do povo paraense, pois, além dos citados anteriormente, o vídeopropaganda mostra ainda uma mulher oriental, um rapaz branco e ruivo, outras mulheres negras e crianças que, nos dois momentos que aparecem, estão participando de festas culturais, remetendo ao sentido de tradição que se é praticada desde a infância.

A cor predominante no vídeopropaganda é o verde. Segundo Amaral Filho (2016), a predominância do verde nas imagens relacionada a Amazônia acaba por representá-la pela floresta,

trazendo uma ideia simplista de que a Amazônia se resume a floresta. Outra cor marcante é o amarelo/laranja que aparece juntamente com muitas imagens de pôr-do-sol na peça publicitária. $\mathrm{Na}$ fotografia, esse tipo de luz alaranjada emitida ao nascer ou pôr-do-sol é chamada de "Hora Mágica" ou "Hora Dourada", trazendo a sensação de paz, nostalgia, o silêncio que também se relaciona com a floresta, e reforçando a ideia de encanto. Em alguns momentos, aparecem cores terrosas, que se relacionam com a cor dos rios da Amazônia, e o roxo, remetendo a cor do fruto do açaí.

Os enquadramentos, planos e movimentos de câmera são fundamentais para a narrativa de um vídeo. Isso porque, como afirma Martín (2005), a câmera deixou de ser um mero objeto que registra objetivamente os acontecimentos e passou a ser uma intérprete da realidade. O realizador do vídeo planeja como determinada coisa será contada, como e qual discurso será transmitido no momento que escolhe quais elementos 


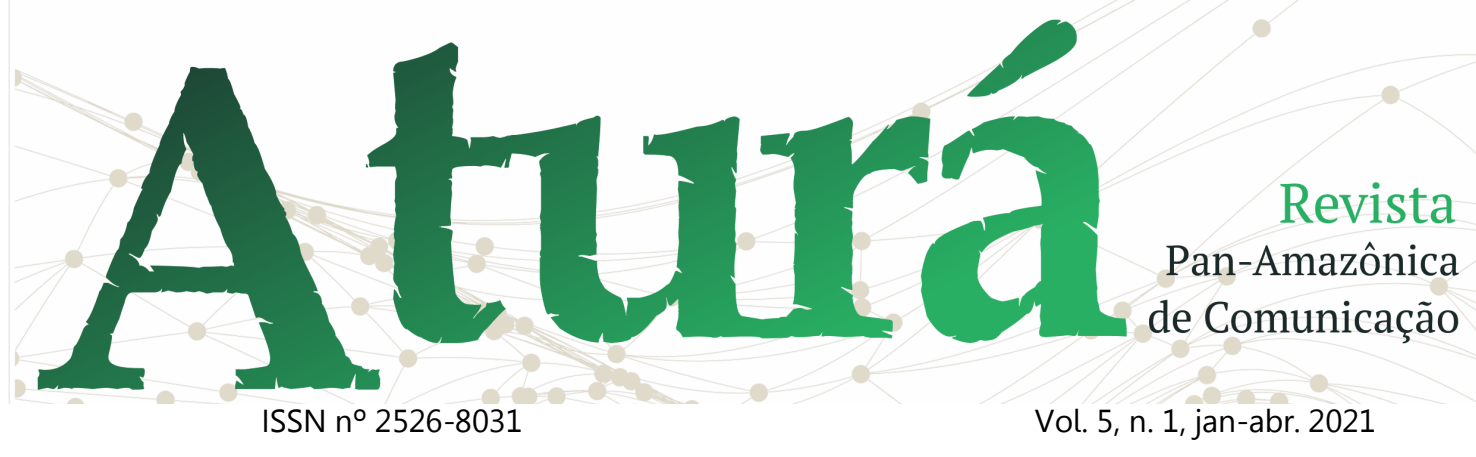

ficarão de fora do quadro; a quais elementos dará maior ênfase; sob qual ângulo será mostrado, podendo, inclusive, modificar o ponto de vista natural do espectador.

No vídeo-propaganda analisado, a maioria dos planos são amplos com muitas tomadas aéreas e panorâmicas. Esse tipo de plano tem como objetivo descrever o ambiente e transmitir a ideia de grandiosidade. Assim, apresenta cenas de florestas tão amplas que se perdem no horizonte, em toda a sua exuberância. Faz relação com a música que diz "Vem ver esse Estado gigante". Em alguns momentos é realizado o movimento de câmera de afastamento (travelling para trás ou zoom out) que também constrói esse sentido de amplitude. Em uma das cenas, a câmera viaja sobre a copa das árvores mostrando a floresta sem fim. Uma neblina suave acrescenta e reforça a ideia de floresta misteriosa, encantada, como seriam as dos contos de fadas. Em alguns momentos, a câmera realiza um movimento de travelling ou panorâmico que revela, pouco a pouco, cidades ou

cenários urbanos que parecem surgir em meio à floresta, reforçando a ideia de sustentabilidade citada anteriormente.

Em outro momento, ao falar sobre "o verdadeiro açaí", a câmera enquadra um senhor segurando um cacho de açaí em contra-plongée (ou contrapicado, quando o assunto é enquadrado de baixo para cima), atribuindo superioridade, triunfo, exaltação, orgulho. A edição do vídeo acompanha o ritmo da música e faz referência à ideia do povo alegre e festeiro do Pará.

Quanto à sonoridade, o comercial apresenta efeitos sonoros relacionados a floresta, como sons de canto de pássaro, do vento balançando as folhas e de água corrente. Alguns desses elementos nem aparecem no vídeo-propaganda - como animais, por exemplo - mas o som é reproduzido de modo a oferecer a ambientação da floresta e transmitir uma sensação agradável de paz e relaxamento. Em alguns momentos, como na primeira cena do vídeo-propaganda, pode-se ouvir o som de tambores, remetendo ao povo da floresta. Em determinado 


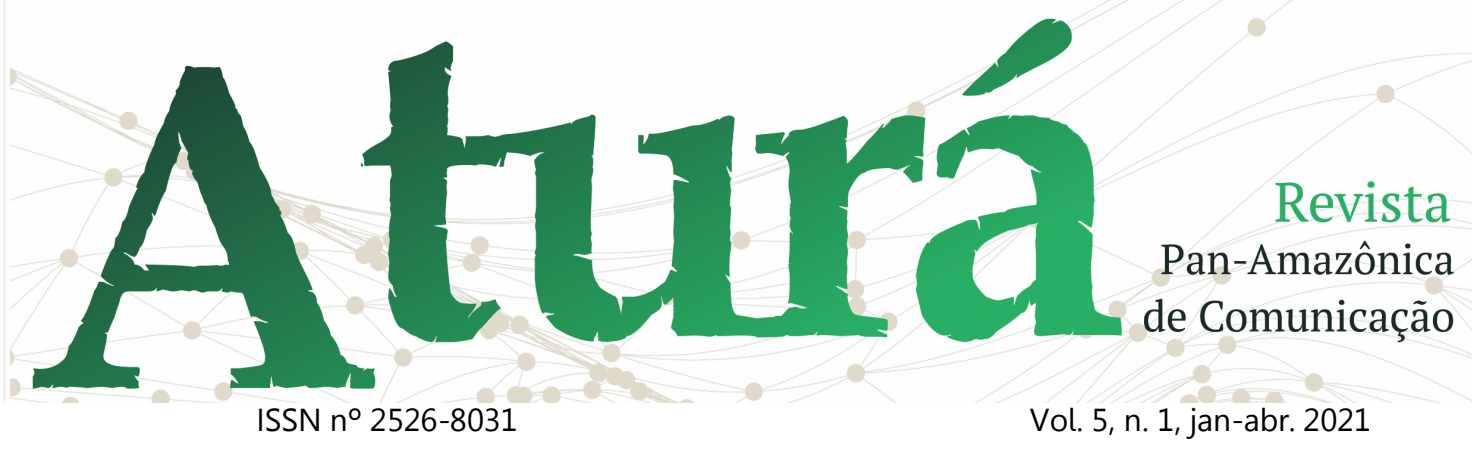

momento, esse som de tambores dá lugar ao som da guitarra - instrumento muito presente nas músicas típicas paraenses. A partir daí, as cenas ficam mais rítmicas e começam a aparecer imagens mais urbanas, da cidade e de pessoas.

A música é cantada inicialmente por um homem. Logo no começo, à medida que ele canta suavemente, acompanhado pelos sons dos tambores e efeitos sonoros de vento e ondas quebrando, combinando com a ideia de paz e tranquilidade, são mostradas imagens de florestas e paisagens naturais. Esse contexto do início do vídeopropaganda se assemelha a alguém que conta uma história, um "era uma vez" de um lugar diferente e encantado. $O$ refrão da música é cantado por uma mulher, o que pode remeter à ideia de sedução, de convencimento, pois a voz feminina convida repetidamente "vem", "deixa o Pará te encantar".

Outra questão que também podemos citar é como a letra da música fala de várias culturas, exalta as misturas e costumes diversos, porém o vídeo- propaganda acaba colocando toda essa diversidade dentro de uma espécie padrão que mostra a Amazônia de forma homogênea e resumida em relação a identidade cultural paraense. Esse padrão carrega diversos estereótipos que, como afirma Amaral Filho (2016), representa a visão do estrangeiro. Mostra a Amazônia como patrimônio mundial e, ao mesmo tempo, lugar dos povos tradicionais, e como o Eldorado ou como o Pulmão do Mundo.

Ainda de acordo com Amaral Filho (2016), ao falar sobre Marca Amazônica, declara que essa marca representa uma síntese idealizada de agregação de valor ao produto que busca influenciar $o$ consumidor. No vídeo-propaganda vemos o Pará como um produto destinado ao turista consumidor e é possível perceber as características dessa Marca Amazônia associadas ao produto, como mostra Amaral Filho (2016). Não existe o termo "Amazônia", porém ocorre a apropriação de seus elementos constituidores, como a paisagem, suas populações, referência aos animais, a 


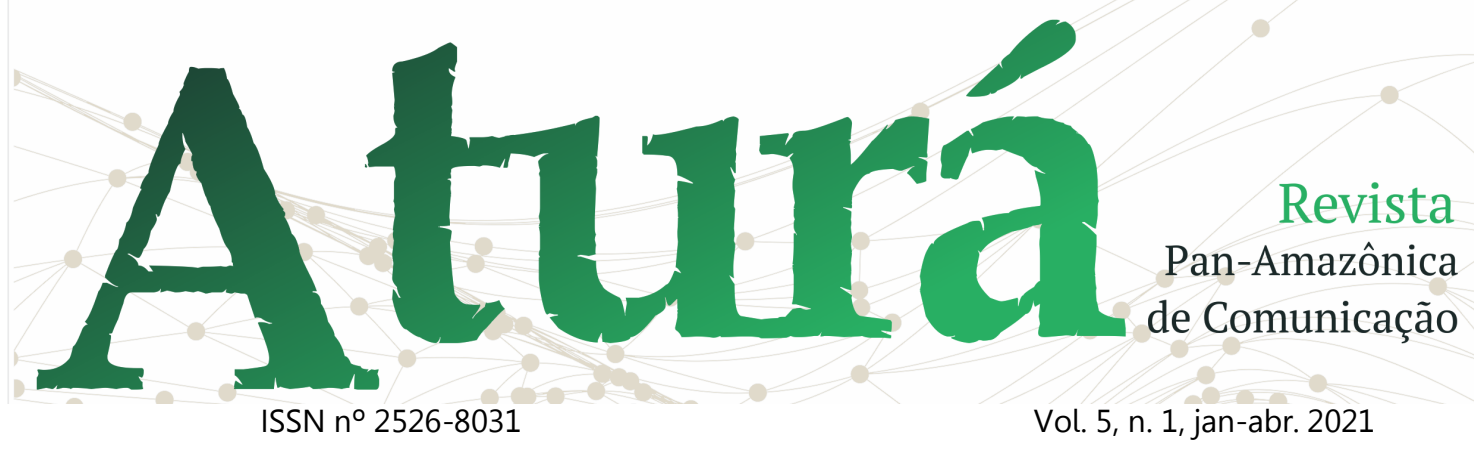

madeira, o açaí. Há, também, a ideia de desenvolvimento sustentável, e representações do que seriam as identidades e o imaginário amazônico. São mostradas imagens que $O$ autor chama de conceituais, como a Amazônia dos espetáculos culturais; a selva e o selvagem; povos da floresta; a tradição, conhecimento tradicional; a floresta conservada, mata virgem. Também aparecem, ainda conforme o autor, as imagens plásticas que caracterizam a Marca Amazônia: a cor verde; o círio de Nazaré e outros espetáculos culturais; imagens sobre o tamanho da região; imagens dos rios, da cidade e da floresta. plásticos (cores, texturas, formas), das imagens representadas (lugares, objetos, paisagens), das técnicas aplicadas (enquadramento, movimentos de câmera, edição) e do áudio (música, efeitos sonoros).

\section{Conclusão}

Tendo em vista a análise e as reflexões feitas anteriormente, pode-se concluir que o vídeo-propaganda "Pará te encantar" traz representações que corroboram o sentido de Amazônia como um lugar encantado, místico, exótico. São reforçados os estereótipos do Pará como um lugar alegre, de povo acolhedor, onde - turista poderá desfrutar de vários espetáculos culturais e explorar a natureza, o que o torna "um lugar diferente" (como diz no início da música) para experimentar um turismo diferente do turismo de sol e mar.

O comercial não traz imagem de turistas desfrutando dos ambientes, mas sempre mostra pessoas que seriam nativas e exibe alguns aspectos do dia-adia do paraense, como o homem que colhe o açaí, um almoço simples em família e não em um restaurante, pessoas nas suas canoas ou nadando no rio. Isso reforça o sentido de acolhimento e simplicidade relacionados ao paraense e à vida na floresta. Não aparecem imagens que representam também a realidade do Pará e da Amazônia, como o agronegócio, nem de queimadas ou poluição, tampouco dos transtornos da cidade, como as enchentes que 


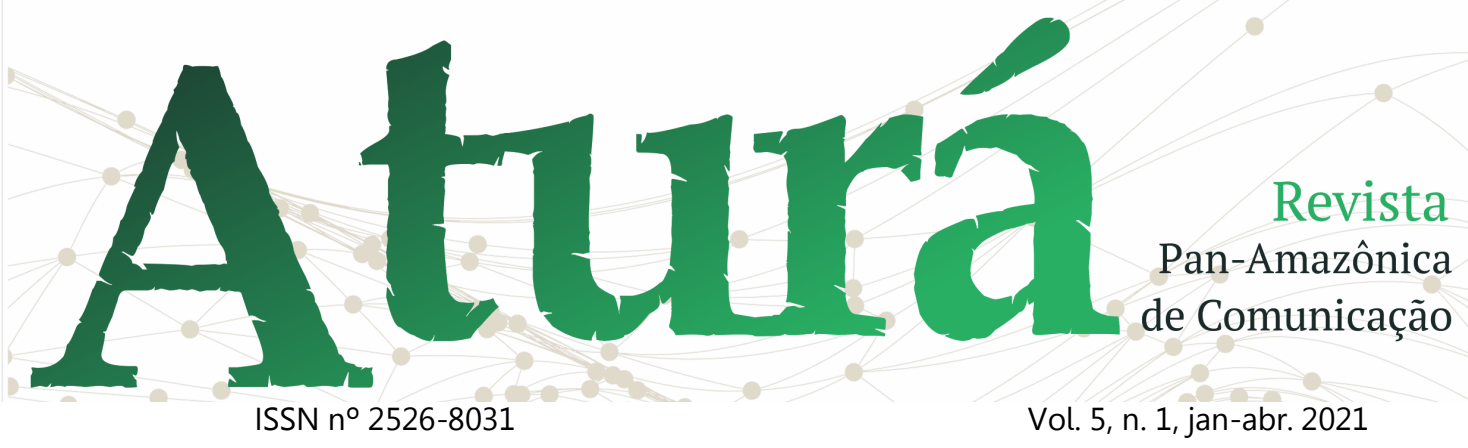

acontecem em Belém nos períodos de chuva. Isso mostra o que foi dito anteriormente sobre as escolhas de composição e enquadramentos que são feitas a fim de construir uma narrativa da Amazônia como local intocado, encantado e com desenvolvimento sustentável.

A floresta é o ponto alto do vídeopropaganda. Mais que isso, a floresta com as cidades próximas a ela, mostradas sempre uma em paralelo com a outra. Por um lado, essa representação tenta desconstruir o estereótipo de que a Amazônia é um lugar inabitado, não civilizado, terra de índio. Por outo, traz a ideia de que viver na região amazônica consiste em estar em harmonia com a natureza e, novamente, remete ao desenvolvimento sustentável.

Para aqueles que nunca tiveram contato com a região Norte do país, principalmente o Pará, além da Amazônia, o vídeo-propaganda traz elementos interessantes da cultura paraense, como a música, a gastronomia e deslumbrantes espetáculos culturais. Esses elementos tornam o comercial um convite para a experimentação cultural, o turismo cultural, com o foco não apenas no passeio, mas em uma experiência diferente, tradicional, um retorno às raízes do Brasil quando em posse dos seus habitantes originais, os povos da floresta. No entanto, percebe-se que a abordagem que se dá é com a visão do colonizador, estereotipada.

Finalmente, entendemos o longo percurso que temos de seguir no debate a respeito das representações da identidade cultural na vídeo-propaganda de turismo paraense, produzida pelo Governo do Estado. Muitas outras questões ainda precisam ser estudadas. No entanto, consideramos que as reflexões iniciais descritas neste artigo servem como base e estímulo para a continuidade da pesquisa proposta.

\section{Referências}

ADORNO, Theodor W.; HORKHEIMER, Max. A dialética do esclarecimento: fragmentos filosóficos. Rio de Janeiro: Jorge Zahar, 1985. 


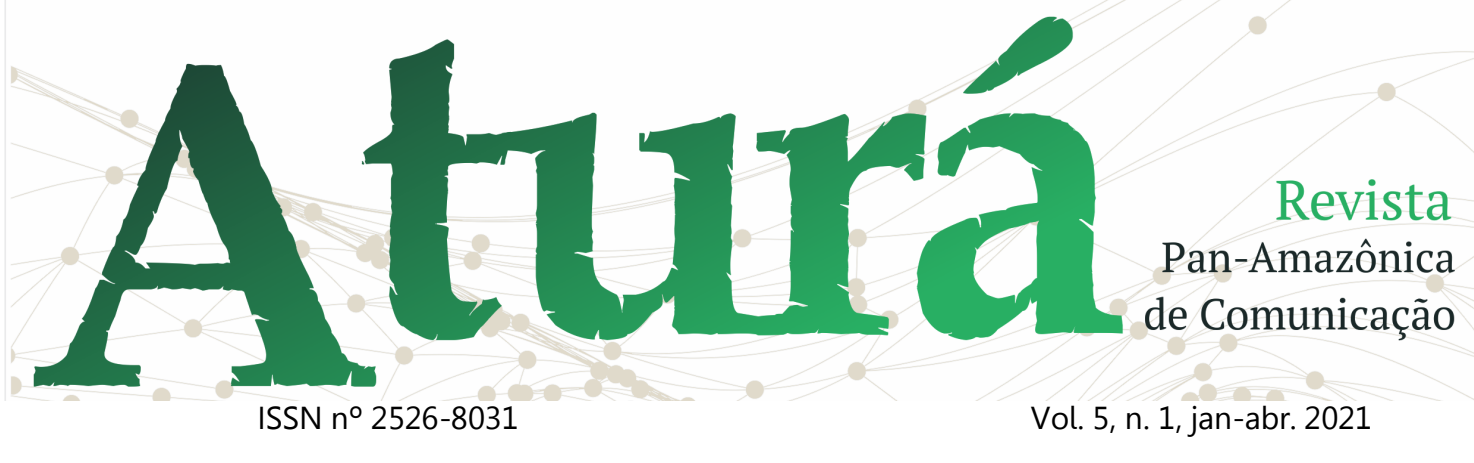

AMARAL FILHO, Otacílio. Marca Amazônia: o marketing da floresta. Curitiba: Editora CRV, 2016.

AMARAL FILHO, Otacílio; CASTRO, Fábio Fonseca de; COSTA, Alda Cristina da Silva. Marca Amazônia: estratégias de comunicação publicitária, ambientalismo e sustentabilidade. Revista de Comunicação Midiática, Bauru/São Paulo, v. 10, n. 3, p.105-118, set./dez. 2015.

BRASIL. Anuário estatístico de turismo. Ano base 2018. Brasília, DF: Ministério do Turismo, 2019.

BRASIL. Índice de competitividade do turismo nacional. Brasília, DF: Ministério do Turismo, 2015.

BRASIL. Estudo da demanda turística nacional. Brasília, DF: Ministério do Turismo, 2017.

BUENO, Magali F. O imaginário brasileiro sobre a Amazônia: uma leitura por meio dos discursos dos viajantes, do estado, dos livros didáticos de geografia e da mídia impressa. Dissertação de mestrado. São Paulo: USP, 2002.

FIDALGO, António. 0 consumo de informação: interesse e curiosidade. Universidade da Beira Interior, 1996. Disponivel em: http://bocc.ubi.pt/pag/fidalgo-antoniointeresse-curiosidade-informacao.html Acesso em: 15 mai. 2019.

GIDDENS, Anthony. As consequências da modernidade. 2.ed. São Paulo: UNESP, 1991.

HALL, Stuart. A identidade cultural na pós-modernidade. 2.ed. Rio de Janeiro: DP\&A, 2006.

LACLAU, Ernersto; MOUFFE, Chantal. PostMarxism without apologies. In: Laclau, E., New reflections on the revolution of our time. Londres: Verso, 1990.

MARTÍN, Marcel. A linguagem cinematográfica. Lisboa: Dinalivro, 2005

ONO, Maristela Misuko. Design, cultura e identidade no contexto da globalização. Revista design em foco, v. 1 n. 1, p. 52 66, jul./dez. 2004.

ORLANDI, Eni Puccinelli. Análise de discurso: princípios $\&$ procedimentos. $8^{\mathrm{a}}$ ed. Campinas: Pontes, 2009.

ORLANDI, Eni Puccinelli. Volatilidade da interpretação: política, imaginário e fantasia. Abralin, 2020. Disponível em: https://www.youtube.com/watch?v=MjCsJ xfiXtg\&t=2558s: Acesso em: 15 mai. 2020.

ORNELAS, Tula; PEREIRA, Marcos Emanuel. Estereótipos e destinos turísticos: o uso dos estereótipos nos folders de uma agência de fomento ao turismo. Caderno virtual de turismo, v. 5, n. 3, p. 9-17, 2005.

SCHAFF, A. Linguagem e conhecimento. Coimbra: Almedina, 1977. 


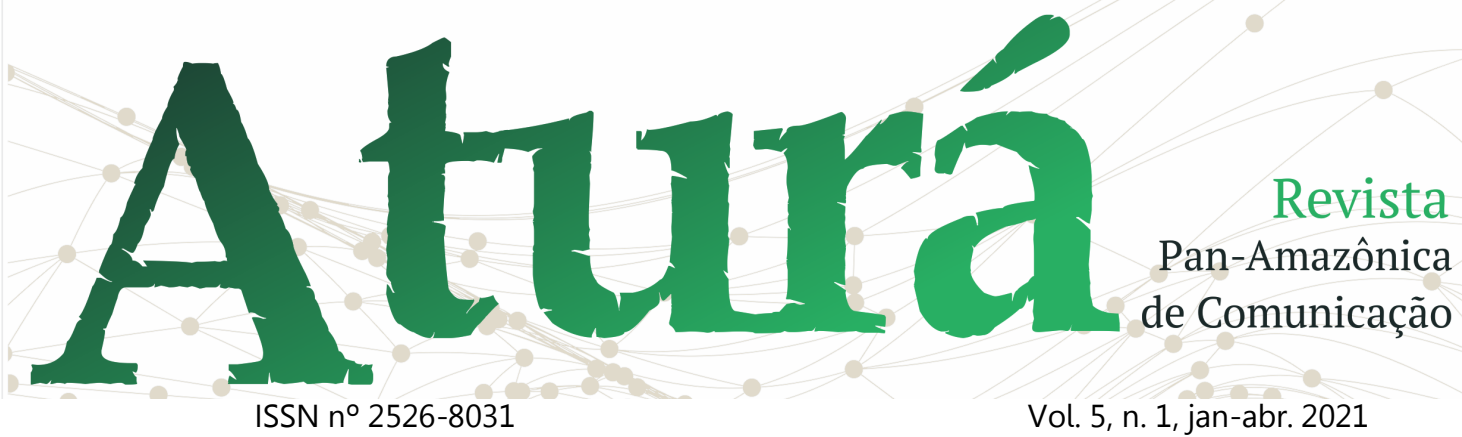

SCHMITT, Brand H. Marketing experimental. São Paulo: Nobel, 2002.

SILVA, Tomaz Tadeu. A produção social da identidade e da diferença.

Petrópolis/RJ: Editora Vozes, 2000.

ZEPPEL, Heather; HALL, C. Michael. Selling art and history: cultural heritage and tourism. The Journal of Tourism Studies, vol. 2, n. ${ }^{\circ} 1$, p. 29-45, 1991. 